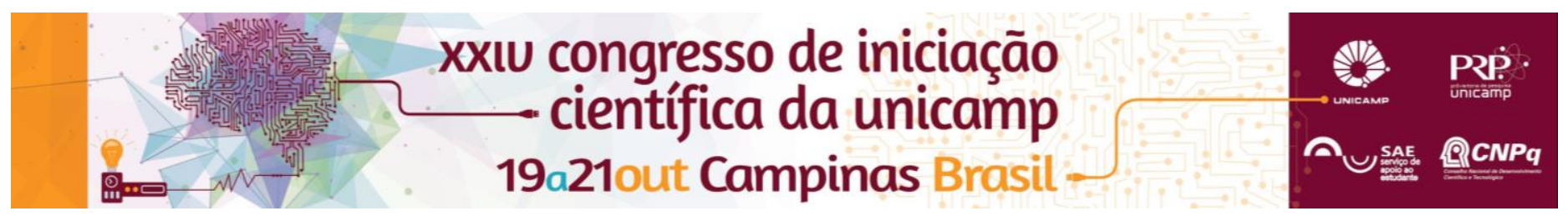

\title{
Análise da recepção crítica da obra 0 Artista-Retrato de Marcellin Desboutin de Édouard Manet.
}

\section{Erica Lelis}

\section{Resumo}

Édouard Manet (Paris 1832 - 1883) foi uma figura extremamente importante para a gênese do modernismo. A partir da análise do debate público sobre as obras de Manet, esta pesquisa de Iniciação Científica tem como o objetivo explorar a recepção crítica de uma de suas obras, O Artista - Retrato de Marcellin Desboutin, que faz parte do acervo do MASP e é uma pintura que ocupa uma posição fundamental como exemplo da nova forma de representação contemporânea, em contraposição com a pintura histórica acadêmica.

\section{Palavras-chave:}

O Artista, Édouard Manet, pintura moderna.

\section{Introdução}

O Salão Oficial de Paris era de grande importância no meio artístico da época, sendo um grande prestígio a oportunidade de expor em um deles. Entretanto, os artistas independentes que não faziam parte do meio acadêmico eram constantemente excluídos dos salões, oque impedia o sucesso em suas carreiras, uma vez que os meios para uma exposição que os conferisse reconhecimento eram restritos.

Porém, alguns artistas recusados nos salões conseguiam reconhecimento popular, um exemplo é Édouard Manet (1832), um artista francês independente cujas pinturas eram constantemente atacadas pelos críticos da academia e eram foco de acaloradas discussões públicas por retratarem cenas do contemporâneo de forma despojada.

Este projeto de Iniciação Científica tem como objeto de pesquisa a obra O Artista- Retrato de Marcellin Desboutin (1875) de Manet, visando à análise da recepção crítica desta pintura, que é um exemplo fundamental da nova abordagem do personagem contemporâneo.

\section{Resultados e Discussão}

A partir do estudo da bibliográfica sobre a obra escolhida e a revisitação da pintura no MASP onde ela está exposta, percebe-se que as pinturas de Édouard Manet, expostas tanto em salões oficiais quanto extraoficiais, eram motivo de grandes debates públicos, muitas vezes com um cunho político envolvido, uma vez que o pintor colocava figuras comuns do cotidiano em evidência.

A figura monumental e solitária de O Artista é um exemplo claro desta escolha pela representação despojada do contemporâneo. Marcellin Desboutin, gravador de profissão, foi retratado em grandes dimensões 195,5 x $131,5 \mathrm{~cm}$, a partir de uma paleta restrita onde se predominam tons terrosos. A temática desta obra aliada a seu tamanho foi recebida como uma afronta ao público e a pintura foi recusada no Salão de 1876.

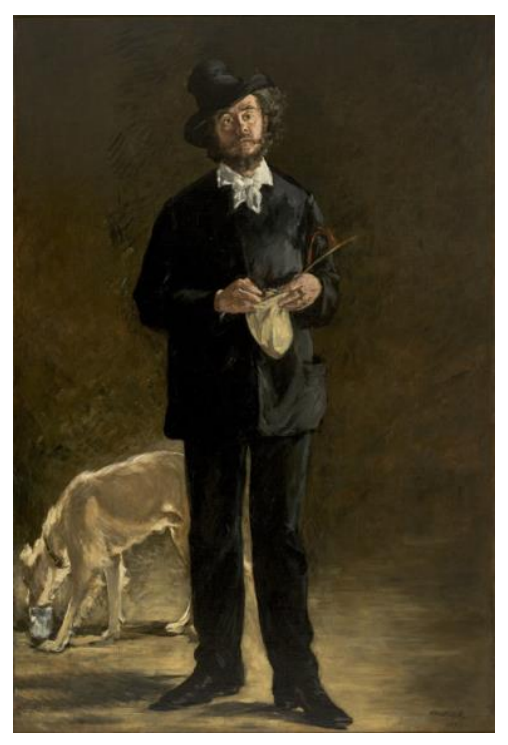

Figura 1. O Artista- Retrato de Marcellin Desboutin.

\section{Conclusões}

Édouard Manet foi uma figura essencial na gênese do modernismo e apesar de algumas de suas pinturas serem rechaçadas pela academia, o artista possuía uma boa reputação entre os artistas independentes da época. Portanto os argumentos favoráveis sobre a forma que Manet representou o contemporâneo na obra $\bigcirc$ Artista evidenciam que os cânones acadêmicos estavam sendo postos em questão, o que posteriormente enfraqueceu o domínio acadêmico sobre as exposições de arte, enfatizando a mudança de gosto na França no século XIX.

\section{Agradecimentos}

A instituição que fomentou esta pesquisa foi o Serviço de Apoio ao Estudante (SAE). 